\title{
Releasing Higher Education from its elitist captivity: The change agency of Unisa's Chance 2 Advance programme
}

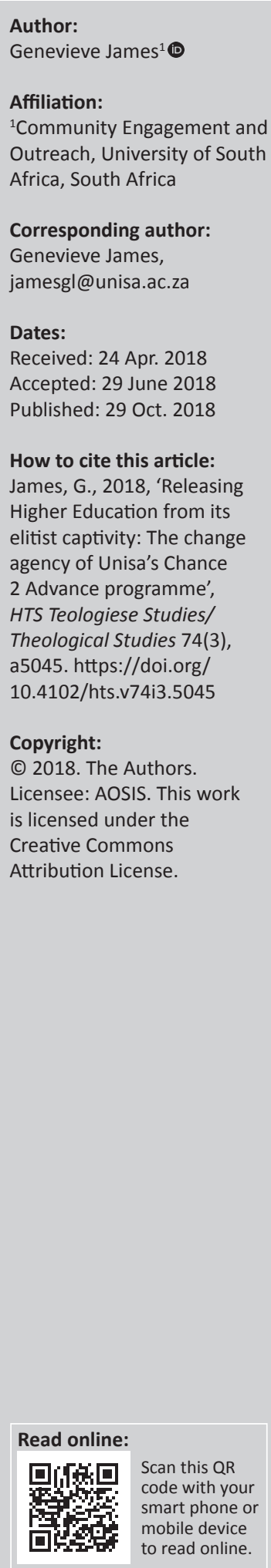

In South Africa, the majority of the population suffers from the inadequacy of learning opportunities and poor access to the higher education system. This causes the widening of the knowledge gap and increased socio-economic marginalisation, which threatens community agency. Critical knowledge created by academics at South African higher education institutions often culminates in access-controlled, costly scientific publications, thus limiting public access. On the other hand, because of the distance between universities and communities, community knowledge and intelligences are never fed back into the university to enrich scholarship and enhance relevance. This paper explores the need for higher education to be freed from its elitist captivity in order to widen access to knowledge that would enhance community agency and revitalise academic agency for social change. The paper starts with a discussion on the need for change in the elitist nature of higher education. I will recount how essential shifts in thinking and action created the Chance 2 Advance programme hosted by the largest provider of higher education on the continent, the University of South Africa. This programme was designed in an attempt to re-vision academic scholarship for the benefit of the poor. Chance 2 Advance is an engaged scholarship and community-learning programme designed to bring communities and academics closer, in a mutual and reciprocal process of knowledge creation and knowledge mobilisation for social change. The programme has been replicated in urban and rural areas with success. At the end of 2018, the programme is poised to reach 100000 participants, since its inception in 2010.

\section{Introduction}

\section{What needed to be changed?}

Higher education has long been accused of being an eager consort to the elite, while concurrently punishing ordinary citizens through exorbitant fees, laborious entry requirements and the ringfencing of scientific endeavour. Historically, communities found themselves at the mercy of the elite, who desired a downtrodden servant class to maintain their exclusive status. While the poor were always beneficial to higher education institutions (as either objectives of research enquiry, or messengers, cleaners and gardeners), there was a general exclusion of the poor and marginalised in the critical work of knowledge creation.

The practice of the intentional marginalisation of communities through the restriction of access to higher education is not novel. Before apartheid, this practice was prevalent in colonial times. Higher education was deployed as a remarkable power tool through the careful gatekeeping of the higher education system. Colonisers wanted to mitigate the impact of higher education on the citizens of the lands they conquered. In India, the British regretted their earlier decision to create access to higher education as part of their 'civilising mission' in the colonies (Mamdani 2008:4). For the British, the unintended consequence was that those who accessed higher education became part of the critical, educated class, who then served as a catalyst for India's nationalisation. Colonial official Lord Lugard termed the situation 'the Indian disease', cautioning that such a situation should not recur in Africa (Mamdani 2008:4). Against this backdrop, Mamdani explains that higher education on the African continent suffered under colonial rule, as evidenced in the low (sometimes non-existent) number of universities (Mamdani 2008:5) in colonial territories.

In South Africa, after centuries of colonisation, decades of apartheid and now over two decades into democracy, student and civil society movements brought to the fore the anxious desire of citizens to access quality higher education. The disequilibrium in the provisioning of and access to higher education perpetuated by the evil trinity of colonisation and apartheid 
followed by a period of devastating, rampant corruption in the democratic era contributed to gross socio-economic disproportionalities and the rise of a knowledge elite, leaving the majority of the country in an appalling postcolonial and post-apartheid education disadvantage. This disadvantage has widespread and weighty consequences that include massive unemployment, chronic poverty and unrelenting inequality.

In view of the challenges described above, the South African Department of Higher Education and Training released the White Paper in Post School Education and Training (2013) in an attempt to widen access through the differentiation of education opportunities made available on completion of school. The White Paper notes three serious impediments in community learning. Firstly, that 'communities have learning needs that have not been catered for by the current public education and training institutions' (2013:20). Secondly, that 'the education and training system must find ways to cater to the needs of the millions of adults and young people who are unemployed, poorly educated and not studying' (20), and finally that '...education opportunities for adults and postschool youth have been insufficient and their quality has been generally poor' (21).

\section{According to educationist Stan Lester (1996):}

if an individual's or society's learning is equal to the rate at which its environment is changing, on balance the result will be functionality and effectiveness: the individual, or society, will for most of the time be equal to the challenges of their environment rather than a victim of events. (p. 3)

On the flip side, Lester notes, 'if learning is inadequate in relation to context, it will produce ineffectiveness, dysfunction and structural blocks, leading in a downward, pathological direction' (p. 3). When abandoned and ignored, communities become vulnerable to socio-economic injustice. This leads to a state of arrested development and growing instability in affected communities. According to Sagasti (2001):

millions of individuals, particularly in the developing world, are ill-equipped to be part of an emerging global 'information society' due to factors such as inadequate education, social and political exclusion, and sheer lack of financial resources. (p. 43)

Learning inadequacy that arises from the context described above causes the widening of the knowledge divide. This divide isolates those who struggle to access, critically engage with and apply knowledge. Like the increasing divide between the rich and poor, the knowledge divide threatens the very survival of the poor and marginalised, leading to a daily existence which revolves around the fight to survive amidst a social order characterised by inequality, dysfunction and knowledge deficiency. This situation is untenable for the strengthening and deepening of South Africa's fragile democracy. In the case of South Africa, the marginalised are not the hidden minority but highly visible masses, which make up the majority of the citizens of our land.

\section{The opportunity for change}

I joined the University of South Africa (Unisa) as a lecturer in Missiology in 2006. Two years later the university launched its pilot Young Academic Programme in which younger scholars were carefully selected from various academic departments to participate in a training and mentorship programme that would facilitate a greater knowledge of the higher education system and exposure to the academic and operational work of the university. The programme encouraged participants to think critically, discern university challenges and explore possible solutions. We were encouraged to challenge the status quo and question higher education orthodoxy. In one such exercise, I suggested that the university share its knowledge with communities to contribute to nation building and sustainable development.

A year later, in 2009 Unisa sought to establish a Summer School presenting the paying public a selection of workshops and public lectures. After being invited to participate in a think tank to discuss the possibility of a Unisa Summer School, I suggested that the model did not resonate with the Unisa context, which at the time operated on an Open Distance business model where operations did not close for the summer. Essentially western in design, the Summer School model was developed primarily for residential universities that recess for the summer period. During the period of closure for the summer holidays, university management deploy vacant university facilities for the implementation of Summer Schools in order to attract participant fees as an additional income stream. From an exploration of the existing Summer Schools in the South African context, I noted that the workshop offerings were not primarily targeted to those struggling to access the postschool education system (the majority of the country). Instead, most offerings can be best described as elite and pandering to the curious affluent. I saw this as a unique opportunity for change. The elite Summer School model had to be swapped for a liberating education approach. In this regard, my thinking was shaped by the work of Julius Nyerere who positioned education as a tool for the social, economic, psychological, cultural, physical, intellectual and spiritual emancipation of individuals and societies, thus increasing agency (Nasongo \& Musungu 2009; Sanga 2017).

Instead of getting the public to the university for an elitist range of Summer School offerings, university academics could now encounter communities in context, developing partnerships for social change. The head of the task team encouraged my thinking in this regard. She gave me the freedom to share this alternate idea and encouraged me to pursue the changes I had envisaged. For her, it did not matter that I was a 'Young Academic', it mattered that I had an idea for the transformation of higher education from elitist to egalitarian. I soon found myself seconded from my academic department to conceptualise, design, operationalise and implement the new project that would assume the painstaking work of breaking the walls between the academy and South African communities. 
Before I began, I realised that it was necessary to review the inherent purpose of higher education. Nelson Mandela clearly illuminated the link between education and world change when he stated that, 'Education is the most powerful weapon which you can use to change the world' (De Villiers 2018). Elsewhere, and in an earlier time (1899), the first president of the University of Chicago, William Rainey Harper, moved by the Social Gospel, considered the purpose of the university in sacred terms. He (in Benson \& Harkavy 2000:179) described the university as 'the strategic agency to nurture good citizenship and intensify democracy'. He continued:

It is the university that fights the battles of democracy, its war-cry being: 'Come, let us reason together.'

It is the university that, in these latter days, goes forth with buoyant spirit to comfort and give help to those who are downcast, taking up its dwelling in the very midst of squalor and distress. (Harper in Benson \& Harkavy 2000:179)

The purpose of higher education as seen through Harper's eyes is to be present amongst the distressed. The Latin roots of the word education, educo means to draw out, to lead out or raise up (WordSense 2018). Against this backdrop, the significance of higher education for democracy and development is considerable. The inherent purpose of higher education seeks to draw citizens out of injustice, isolation, individualism and self-absorption; then, through transformed citizens and effective collaboration with communities, higher education raises nations towards humanity, community and social justice.

\section{Shifts in thinking and action required to design the initiative}

With this understanding, I will now proceed to explore the essential shifts in thinking and action that were required to design the Chance 2 Advance programme as a tool for the liberating of education. I will unpack these shifts, which included from elitist to pro-poor, from community engagement as a separate activity to integrated scholarship, from ivory tower to grass roots, from disengaged to engaged scholarship, from knowledge hording to knowledge mobilisation, from working for communities to working with communities.

\section{From community engagement as a separate activity to integrated scholarship}

In order to approach the significant task ahead of me, I needed to acquaint myself with the South African Higher Education policy landscape. I noted that the higher education system did attempt to bring the needs of society closer to the consciousness of academics. The South African Higher Education Act of 1997 positioned Community Engagement as core business together with teaching and research (Hall 2010:1-3). The problem is that the three principles of higher education are often seen as separate activities. This perpetuates silo thinking, which does not lend itself to integrated scholarship. According to Hoyt and Hollister (2014): the integration of research, teaching and service through civic engagement expands both the sites and the epistemologies of knowledge, focusing on the production of knowledge that is relevant and crucial to solving pressing societal problems. (p. 129)

At Unisa, the Academic Plan (2015) of the university states:

community engagement can only be successfully implemented where it is integrated with teaching and learning, and research and innovation to produce coherence in scholarship. The lens through which community engagement must be implemented and performance assessed has to be through the lens of teaching and learning, and research and innovation. (p. 11)

I realised that the new project could not merely replicate the silo thinking. The design of the project had to demonstrate synergy with the university's Academic Plan, demonstrate a link between teaching, learning and community engagement and meet development goals. In order to do this, a shift from ivory tower to grass roots was required.

\section{From Ivory tower to grass roots}

Instead of the public attending a costly, border-controlled Summer School hosted at the university, I encouraged academics to leave the insulation of the academy and encounter communities in context. This departure from the ivory tower to grass roots would facilitate a change from a detached and disengaged approach to community learning problems, to a more connected and collaborative approach. When academics leave the familiarity and comfort of their higher education institutions and encounter the phenomena about which they write, this facilitates a contextualised, socially responsive mode of scholarship.

Design Thinking was the chosen method or style of thinking in the conceptualisation of the project. Waloszek (2012) describes Design Thinking as essentially user-centred, combining 'empathy for the context of a problem, creativity in the generation of insights and solutions, and rationality and feedback to analyse and fit solutions to the context'. Moving from the ivory tower to the grass roots provided me with plentiful opportunity to observe the context of the communities the programme was to engage with. After seven years of working in hundreds of South African communities, both urban and rural, I personally observed the following contextual commonalities:

1. Far from the common misconception that youth are lazy and troublesome, I found that the young people in the communities that the programme served were hungry for knowledge, human connection, and digital connectivity.

2. I observed that healthcare was in a general state of crisis with death and dying being the order of the day. A drive through the participating communities revealed the long lines that stretched around local clinics, with many of the sickly, injured and aged queuing from 5 am or earlier to secure their place. I observed that the healthcare system was brutal to those who could not afford private care. Community members seem to attend more funerals than any other occasion, and this was evident in the number of funeral businesses that were available in distressed communities. 
I observed that there was a hierarchical approach to the value of life. The more resources you had, the higher up the hierarchy you were positioned, enabling you to access the best healthcare. Those without resources find themselves in a perilous condition, having to resort to phony faith healers and an army of dodgy 'doctors' who possess magical powers that can treat everything from erectile dysfunction to depression caused by a failed relationship.

3. Communities suffered intolerable levels of crime, gender violence and child rape. One grandmother explained how she had saved portions of her monthly grant for years in the hope of purchasing a small, basic microwave. On the day that she finally purchased the product, she was a victim of rape and robbery. In addition to the indignity and shame of the rape she suffered, she also wept over the years she painstakingly saved to buy the microwave. I realised that the poor were at great risk. Criminal activity was violent and pervasive. Crime was under-reported because communities lost faith in the country's criminal justice system. This lack of trust as a result of inadequate access to safety and security and the failure of the rule of law has led to incidents of community justice. In the South African context, this relates to communities taking the law into their own hands to apprehend and punish suspected criminals, sometimes leading to the killing of suspects. I also found that more needed to be done in terms of exposing communities to the provisions of the Constitution and the Bill of Rights.

4. Illicit drug use and alcohol addiction are widespread, with the age of drug users decreasing and the number of substance abusers increasing. The communities had to contend with the proliferation of taverns making alcohol easily available at any time of the day and night. The homes of tavern owners dwarfed the houses surrounding them, displaying their economic success. While the owners and their families flourished, the members of the communities were exposed to addiction, death, violence and rape as a result of the prevalence of taverns.

5. I identified power struggles between civil society organisations that were supposed to have the best interest of the community at heart. Given the impact of the global economic crisis, many NGOs struggled to sustain their activities, leading to increased competition over limited resources.

6. Even though the neighbourhoods of the communities served were covered in electioneering posters and political party paraphernalia, when voted into power, the political leaders generally did not serve the interests of the community, focusing rather on wealth accumulation and establishing a power base. Service delivery protests are a regular occurrence. Poor service delivery is not an exception but the norm, with communities developing their own means of acquiring the services they need, including dangerous and illegal electrical connections causing power outages, burns, wounds and even death.

7. The Native Land Act still impacts on spatial justice over a hundred years later. Landlessness is still a major issue, with many communities seeking shelter in informal settlements. Communities battle food and water insecurity, widespread environmental degradation and the constant threat of eviction.

8. Despite having inadequate access to higher education and the spectrum of offerings of the South African post-school education system, I observed that communities possessed embedded knowledge and local solutions for local challenges.
Despite the overwhelming challenges, communities were resilient and had an insatiable desire to overcome their trials. In numerous communities that I visited, communities appealed for closer links with higher education institutions to aid their development efforts.

Against this backdrop, the programme collaborated with academics, relevant stakeholders and community dialogue partners to unpack learning needs that would build academic and community agency to address the challenges listed above and other challenges facing the community.

Even before the pilot programme in 2011, during an extensive period of research and stakeholder engagement, the programme joined with the municipality of Tshwane, businesses and civil society organisations such as the Tshwane Leadership Foundation to implement the Better World Village, a social justice and learning event that coincided with the 2010 Soccer World Cup hosted in South Africa. The Better World Village was set up in a large park in the centre of the city. Massive screens showing live World Cup matches drew large crowds at match times. At the park and in the churches and hotels close to the park, various workshops and discussion groups that dealt with critical social justice concerns ranging from poverty, inequality, migrant justice to gender justice and human trafficking were hosted. During the month-long programme, a small tent was pitched at the park where university students interacted with the public to determine community learning needs, the availability of community learning opportunities and the kinds of knowledge the public desired universities to explore with communities. Together with the feedback from the public, a market research company was commissioned to conduct a similar enquiry, only this time to include a wider sample, more representative of the country's demographics.

In addition to what I observed on the ground, the findings from surveys, the information shared by dialogue partners and the body of knowledge I explored, key policy and development documents were consulted as they became available. These included the National Development Plan (2012), the White Paper in Post School Education and Training (2013), Africa 2063 (2015) and the Sustainable Development Goals (2015). All these avenues were explored in the creation of the range of relevant and user-friendly workshops for public benefit. Over 100 free workshops were designed and facilitated by Unisa academics, academics from other universities and experts in government, civil society and business.

The project became officially known as Chance 2 Advance in 2011. Communities continue to request the Chance 2 Advance team to visit their neighbourhoods and explore the learning needs of the community. Upon commencement of the programme in a particular community, thousands of community members attend the free informal learning offerings made available under the following themes: Career and Work; Money and Business; Maths, Science 
and Technology; Community Development and Active Citizenship; Environmental Sustainability; Social Justice, Human Rights and the Law; Health, Lifestyle and Creative Arts; Education (schools and colleges); and Faith Communities and Development.

As explored earlier, admission is open, ensuring wide participation and the inclusion of excluded communities that have little access to learning opportunities. Instead of being restricted to the summer period, the programme uses campaign methodology to ensure dynamism, and strategic and timely action to arouse community agency and mobilisation. Communities become empowered to address critical issues in a constructive manner and develop creative ways of engaging with power. In many contexts, this is critical given the propensity for community violence and public disorder.

The objectives of Chance 2 Advance are as follows:

- Promote a culture of learning in communities that have limited access to formal or informal learning opportunities.

- Build bridges between communities and higher education institutions for the purpose of engaged scholarship and development collaboration.

- Improve communities' access to relevant, user-friendly knowledge and skills training.

- Improve academics' access to communities, their knowledge and intelligences.

- Enable communities to work with higher education towards the realisation of the National Development Plan (South Africa), Africa 2063 (African Union) and the Sustainable Development Goals (UN).

- Better inform, equip and prepare communities for life, study, work, community participation, social justice and active citizenship.

- Create opportunities for people who are generally excluded from formal learning to be part of a community of critical and creative thinkers and agents of change.

\section{From elitist to pro-poor}

As a missiologist, I wanted to ensure that I not only reflected on the Missio Dei but also participated in it. I saw theology as science demanding action. I understood that justice and care for the challenges and indignities of the poor was an abiding theme that stretched across the Old and New Testaments. Having been exposed to the thinking of the proponents of Black Theology, Feminist Theology, Liberation Theology (Latin America), Dalit Theology (India), Mingjung Theology (South Korea), Liberation Psychology (El Salvador) and the Black Consciousness Movement (South Africa), I was of the conviction that a critical value espoused by the programme should be a preferential option for the poor and oppressed (Gutierrez 1973).

The original Summer School model did not resonate with the South African context because the Summer School would continue to charge the necessary fees and impose some entry requirements, two barriers that would preclude marginalised communities, which make up the majority of South African society. This would preserve higher education as a tool for the exclusion of the masses. The pilot initiative hosted in the inner city of Pretoria in early 2011 charged nominal participant fees. This was the last time that fees were changed. The programme budget was amended to serve marginalised South African communities at no charge. Some were concerned that this would create a dependency and warned that the programme should charge participant fees, but in contexts where people do not have food security or the taxi fare to travel to the programme, this would once more create barriers that would alienate and exclude participants from a programme designed for their benefit.

The primary target group consisted of community members from distressed communities in particular geographic contexts that struggle to access quality learning opportunities. Community participation has from the onset of the programme been multi-generational, multi-cultural, multilingual and multi-national (migrant communities embedded in our participating communities also attend). It is remarkable to observe how community members learn together despite the differences in age, nationality, language and culture.

While serving marginalised communities, the programme also works with civil society, business, corporates, and education and training institutions that currently service or could serve affected communities. We do this by offering a range of customised, high-quality, capacity-building programmes aligned to suit the unique learning needs of the organisations to better serve their constituents.

\section{From disengaged to engaged scholarship}

Vessuri (2008) calls for rethinking in order for higher education to contribute more meaningfully to the betterment of society:

[the] refusal of the scientific community to assume social responsibility can no longer be sustained because it has led to an out-of-control, conformist science without a conscience. Rethinking is overdue, given the current reality of the world and of certain countries in particular, if higher education and research are to bring about collective well-being and equity in society ... (p. 119)

The call is being answered, as around the world universities are coming out of isolation to seek greater social relevance by articulating a renewed commitment to public engagement (Hoyt \& Holister 2014:129). Scholars observing this new movement state that, ' $t$ ] he fully engaged university has become the preferred model, even the gold standard' (p. 129).

According to the John D. Gerhart Center for Philanthropy and Civic Engagement in Cairo, the 'engaged university' actively develops strong relationships with communities and brings resources to bear on the improvement of life for community members, while advancing and enhancing 
scholarship. The New England Resource Centre on Higher Education defines engaged scholarship as:

the collaboration between academics and individuals outside the academy - knowledge professionals and the lay public (local, regional/state, national, global) - for the mutually beneficial exchange of knowledge and resources in a context of partnership and reciprocity.... It seeks to facilitate a more active and engaged democracy by bringing affected publics into problem-solving work in ways that advance the public good with and not merely for the public (John \& Gerhart Center for Philanthropy and Civic Engagement n.d.).

Van de Ven and Johnson (2006:809) suggest engaged scholarship is a reformation 'to break down the insular behaviours of academic departments and disciplines' (see also Boyer 1990). Through an understanding of engaged scholarship, I discovered that community engagement is more than the third leg of the higher education table, it is an indispensable academic method breaking the barriers between society and the academy, stimulating the conscience and consciousness and arousing action towards the enhancement of scholarship and the betterment of communities.

\section{Estabrooks et al. (2008) argue that:}

science and society are in the midst of a far-reaching renegotiation of the social contract between science and society, with society becoming a far more active partner in the creation of knowledge.

When academics recognise and engage with the knowledge embedded in communities, the inbreeding and exclusionary nature of scholarship, that is, scholars citing, exploring and refuting other scholars views will change. The circle of scholarship will expand. Academic voices will co-exist with non-academic voices creating an engaged scholarship that is respectful and appreciative of the unique and perceptive contributions of non-academics. For example, when academics write about the increasing gap between the rich and poor, they could simply explore the literature available and regurgitate the content, adding their arguments to the existing body of knowledge. As an alternate choice, the academics could immerse themselves in a context like the neighbouring communities of Sandton and Alexandra Township, one containing the 'richest square mile in Africa', while the other battles high unemployment, landlessness, chronic poverty and other devastating social ills. Engaging with communities who experience this gap, as critical dialogue partners and interlocutors, will invigorate and enrich the knowledge produced through what Fanon (1968) described as 'thinking in community', as opposed to thinking in cold academic isolation

After grasping the implications of engaged scholarship, receiving my impulse from the praxis cycle developed by Kritzinger (2002, 2009) used frequently in missiological education, I developed a praxis cycle for engaged scholarship (see Figure 1). The cycle starts with a community problem that requires research or the development of curricula. The academic conducts a self-reflection on personal values and critically engages with the schools of thought that shaped the academic's thinking. This is a critical first step in order to deal with personal worldview, predisposition and bias that may influence the direction of the study. Following this, the academic reflects on the body of knowledge, related policy and local and international development goals. A critical aspect of the cycle involves dialogue with the affected community on the context of the problem. This reflection and consultation feeds back into the design of concepts, types, theories and solutions. It is at this point that the curriculum or research paper takes shape. The solutions are implemented in consultation with stakeholders. Following implementation, stakeholder feedback is sought and adjustments are made. The community is consulted as to how to widen access to the knowledge and areas for policy review or formation are explored. During the process new problems are discovered, leading to further exploration.

\section{From knowledge hording to knowledge mobilisation}

According to the International Council for Science (2005):

science is less pluralistic in practice than it could be in principle. The lack of equitable representation has serious negative implications not only for society but also, through systematic under-inclusion of some perspectives, for the range and quality of the research that is produced. Many brilliant minds currently have no opportunity to contribute to science. (p. 12)

Gauging from the Praxis Cycle for Engaged Scholarship, it is clear that community voices can be included in scientific endeavours in a more meaningful manner, leading to more authentic partnerships between the academy and communities. Engaged scholarship is the key to legitimise and democratise the voices of non-academic communities that suffer the banishment and exclusion from the higher education system. Yet, engaging with communities to merely produce knowledge that ends up in restricted-access academic publications defeats the purpose of liberating higher education from its elitist captivity. The knowledge produced by the academic in consultation with the community needs to be freed from its elitist detention. In order to this, knowledge mobilisation is the next critical tool.

Against this backdrop, Chance 2 Advance involves reciprocal knowledge mobilisation from academics and experts to marginalised communities, and then knowledge from communities to academics to ensure socially relevant curricula. Knowledge Mobilisation refers to:

moving knowledge into active service for the broadest possible common good. Here knowledge is understood to mean any or all of (1) findings from specific social sciences and humanities research, (2) the accumulated knowledge and experience of social sciences and humanities researchers, and (3) the accumulated knowledge and experience of stakeholders concerned with social, cultural, economic and related issues. (Read, Cooper \& Levin 2013:24) 


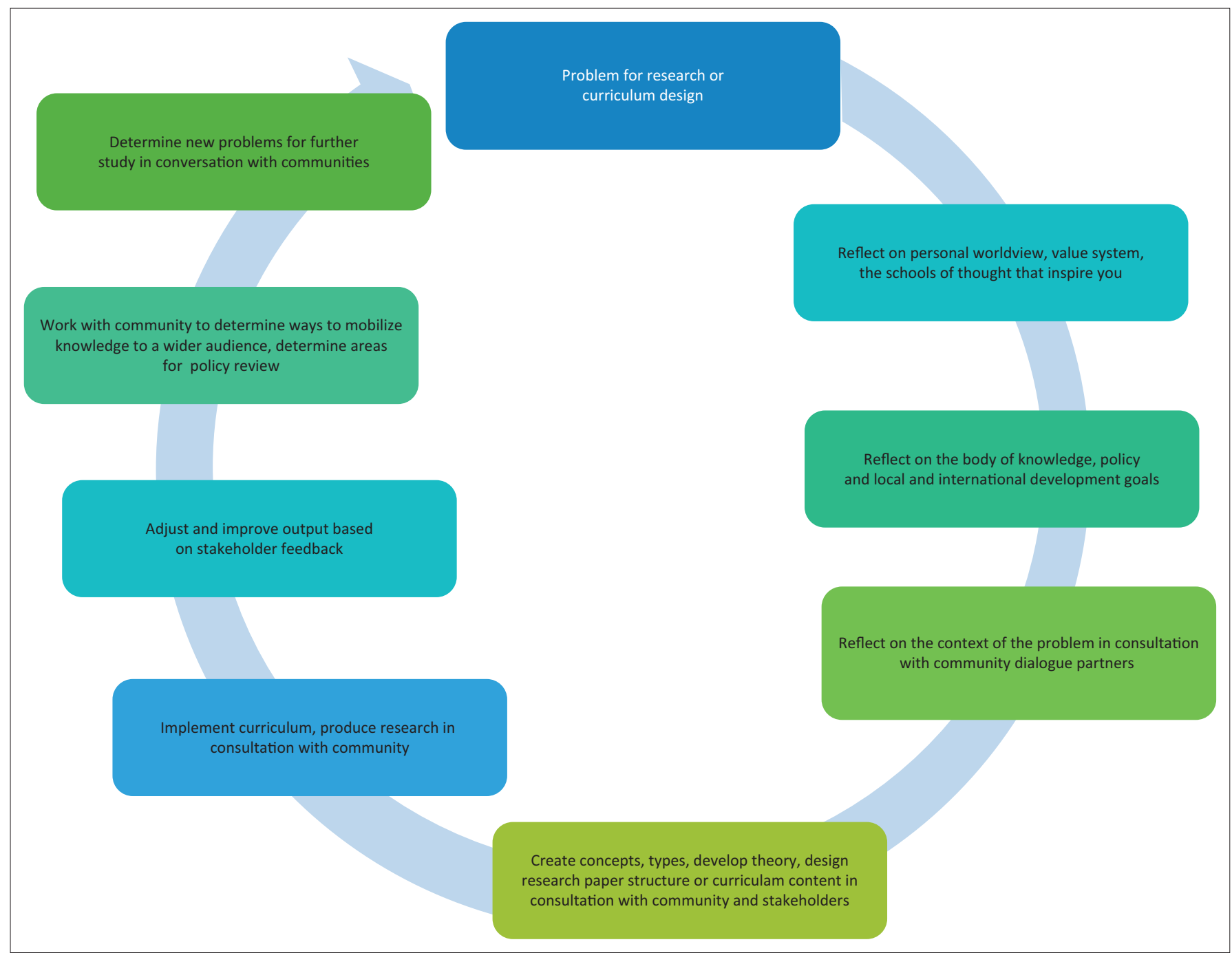

FIGURE 1: Praxis cycle for engaged scholarship.

\section{From Working for Communities to Working with Communities}

Chance 2 Advance collaboration with communities helps break down large challenges into smaller manageable components. It brings advantages on scale and provides an integrated approach to development, nation building and the deepening of democracy through accessible and socially responsive education. Through our collaboration, our networks are expanded, increasing social capital and critical skill sets. Our academic partners support the sound epistemological development of the programme, while our civil society, government and business networks support the design, relevance, implementation and sustainability of the programme.

Community collaboration and support begins at the careful articulation of the community problems and challenges. After identifying critical challenges, the community then proceeds to support the design of the programme's learning and empowerment workshop selections together with Unisa academics. Communities also support the planning, operations and implementation of initiatives. Community members are trained in marketing and communication in order to conduct the marketing and registrations of the programme themselves. To ensure the successful hosting of the programme and its workshops, communities also render support in the provisioning of venues. In some instances, in areas that are increasingly prone to safety and security hazards, community safety networks offer their support to ensure the safe implementation of the programme. Community members are trained in mega event management because our programme can operate in a specific geographic community, in up to 10 large venues with additional medium and smaller venues concurrently. Over and above the operational support, community members serve as knowledge mobilisers who represent all spheres of activity in communities from health, education, business, arts, safety and faith communities. They ensure the sustainability of the programme by deepening community learning in the sphere of influence they represent.

Community businesses and civil society organisations support the implementation of the programme by providing goods and services. Community businesses and civil society organisations also support community participants by employing participants and offering internships. 


\section{Outcomes $^{1}$}

Participants discover the joy of learning and appreciate the link between learning and a better life. Community participants are able to develop their personal and community agency and acquire critical skills that increase the probability of employment. Participants become constructive and ethical citizens and gain a deeper understanding of themselves, their society and the world. Participants are able to interact with experts on relevant subject matter, which in turn bridges the gap between higher education institutions and affected communities. Other outcomes of the programme include the following:

- Liberating education from its elitist captivity, creating access and widening participation in higher education and training.

- Mobilising university research and teaching for the public good.

- Developing academic activists.

- Developing socially responsive curricula.

The programme has been replicated in both urban and rural areas with success. Since inception, over 90000 people have participated in our community learning initiatives, this despite limited resources and a period of severe austerity in the higher education sector. Special cost-saving strategies were developed to increase the potential of the strained budget to reach more community participants. As Lester (1996:11) indicated, 'Learning for the next century will certainly need to involve more people learning more, in order to create a climate which is responsive to change ...'. As such, the Chance 2 Advance programme is now set to cross the 100000 participant mark at the end of 2018.

Through community feedback in the form of class evaluation forms, communication with facilitators, stakeholder feedback sessions and narrative accounts from members of the community, we receive insight from our participating communities on the impact of the programme. We learnt that our community participants and academics gain a better understanding of themselves, their society and the world, improve their health and well-being, acquire skills to increase their probability of employment, become employed, start their own businesses, become aware about social justice and environmental issues facing their community, act to change their circumstances and become critical and constructive citizens.

Participating universities benefit through the engagement with communities. This engagement improves the social relevance of university curricula, research and courseware. Through the programme, universities widen the sites of epistemological praxis. At Unisa, the programme has created an opportunity to share knowledge and research findings with communities. Learning from real circumstances on the ground is being fed into the design of course material and research articles. Our academics have a deeper understanding

1.See Chance 2 Advance website. of social problems and have the ability to connect with dialogue partners in communities to enrich their understanding of social challenges and solutions.

Students develop critical skills for community development and the world of work by occupying key leadership positions in the programme. Students receive training and accompany the programme rollout in different communities. Students also learn to participate as active members of their own communities. Students develop an understanding of community engagement as a social justice imperative and get involved in the community decision-making processes.

\section{Programme evaluation}

In 2013, the Chance 2 Advance model was recognised by a scientific panel, as a best practice in Knowledge Mobilisation at the Global University Network for Innovation in Spain. The programme evaluates its progress through the quality of engagement with communities. Further to this, post-initiative impact discussions, feedback, testimonials, narrative reports from stakeholders and community participants on the impact of the learning opportunities and the resultant changes are considered. Each year the programme submits a Strategic Plan and a detailed proposal of the year's initiatives. At the end of each year, a comprehensive progress report is submitted to the Division: Community Engagement.

From a quantitative perspective, the programme evaluates its statistical reach. This involves the number of: communities reached, participants registered for programmes, participants who actually attended, stakeholders, Learning Ambassadors (knowledge mobilisers who are university students and community members), workshop facilitators, academics, experts from NGOs and practitioners, training sessions for community Learning Ambassadors, initiatives and workshops, case studies used in teaching and learning content and the number of research outputs produced by participating academics.

\section{Challenges}

The first challenge relates to unequal power relations. Academics can behave in a very elitist manner, which could destroy the working relationship between academics and communities. To mitigate this risk, academics undergo a special Chance $2 \mathrm{Advance}$ orientation and learn to understand context and recognise communities as dialogue partners and co-creators in the knowledge mobilisation process instead of 'victims' or mere beneficiaries of academic charity.

The second challenge relates to safety and security. We have had to contend with increasing occurrences of public protests and violence in the distressed and marginalised communities we work with. Given the increasing instability in the communities of implementation, a risk to the safety and security of participating communities, academics and trainers exists. In order to mitigate this risk the community and related safety and security networks are part of the planning and implementation of the programme. 
The third challenge relates to unequal access to ICTs. In resource-poor communities, there is disequilibrium in access to affordable data and Internet access. Because many struggling communities leapfrogged straight to smart phones, it is necessary to develop mobile learning applications in order to address the digital divide. Further to this, local governments must be urged to improve the connectivity of poor communities to mitigate the impact of the knowledge divide, which is perpetuated by the digital divide (see Sagasti 2001).

\section{Conclusion: Key themes regarding change agency}

This paper has highlighted the exclusive and elitist nature of the higher education system that favours the well-heeled while punishing the poor. The problem of the widening knowledge gap and its consequences led to the development of a community learning solution that was designed to create bridges between higher education institutions and society through a process of mutual and reciprocal learning. The paper proceeded to explore the essential shifts in thinking and action that were required to design the Chance 2 Advance programme as a tool for the liberating of education. Key strategies including engaged scholarship and knowledge mobilisation were used to achieve the goals of the programme.

Some key lessons learnt from this exploration are as follows:

1. A personal sense of justice is required to see systemic injustice. One can serve the higher education system without question, or ask critical questions about the relevance of the claims of higher education. If higher education claims to improve individual, community and national development, then why is this claim conditional? Why are only the elite privy to the power of the higher education system, which is knowledge? Knowledge is after all power, power to act, power to restore dignity and power to speak to power.

2. A multi-, inter- and transdisciplinary approach to social problems is the best approach. As evidenced in this paper, a range of disciplines from theology, to missiology, to education, to development intersect to provide an integrated, as opposed to silo-based, solution.

3. A key change agent in the story of Chance 2 Advance was the leader of the task team who served as a change enabler. She could have discounted my alternative thinking from the start. Instead, she encouraged my thinking and provided me the opportunity to turn my ideas into concrete action that was to later impact academics from various higher education institutions and hundreds of South African communities.

4. Through my thinking and action in the development of Chance 2 Advance, I leant that stubborn, ring-fenced and elitist systems can be reimagined and revised for the benefit of the poor and marginalised. The process of democratising education means that communities can indeed become part of the knowledge creation and mobilisation process.
Chance 2 Advance is a higher education initiative that cuts through the borders between higher education and communities, freeing knowledge from its bourgeois captivity. The current context of instability, poverty and inequality must be addressed through a renewed vision of the dynamic change agency potential of South African universities.

\section{Acknowledgements Competing interests}

The author declares that he or she has no financial or personal relationships which may have inappropriately influenced him or her in writing this article.

\section{References}

African Union Commission, 2015, Agenda 2063, African Union Commission, Addis Ababa.

Benson, L. \& Harkavy, I., 2000, 'Integrating the American system of higher, secondary and primary education to develop civic responsibility', in T. Ehrlich (ed.), Civic responsibility and higher education, pp. 174-196, Oryx Press, Phoenix, AZ.

Boyer, E., 1990, Scholarship reconsidered: Priorities of the professoriate, Carnegie Foundation for the Advancement of Teaching, New York.

Department of Higher Education and Training, 2013, White Paper in Post School Education and Training, DHET, Pretoria.

De Villiers, W., 2018, Mandela's belief that education can change the world is still a dream, viewed 21 April 2018, from https://theconversation.com/mandelasbelief-that-education-can-change-the-world-is-still-a-dream-44858

Estabrooks, C., Derksen, L., Winther, C., Lavis, J., Scott, S., Wallin, L. et al., 2008, 'The intellectual structure and substance of the knowledge utilization field: A longitudinal author co-citation analysis, 1945 to 2004', Implementation Science A longitudinal author co-citation analysis, 1945 to 2004 ', Implementation Science
$3(49)$, viewed $21 \mathrm{April} 2018$, from https://implementationscience.biomedcentral. com/articles/10.1186/1748-5908-3-49

Fanon, F., 1968, The Wretched of the Earth, transl. Constance Farrington, Grove Press, New York.

Gutierrez, G., 1973, A theology of liberation: History, politics and salvation, Orbis Books, NY.

Hall, M., 2010, 'Community Engagement in South African Higher Education', in Kagisano No. $6 \mathrm{CHE}$, Community engagement in South African Higher Education, pp. 1-52, CHE, Pretoria.

Hoyt, L. \& Hollister, R., 2014, 'Moving beyond the ivory tower: The expanding global movement of engaged universities' in B. Hall \& R. Tandon (eds.), Higher Education in the World 5, Knowledge, Engagement and Higher Education: Contributing to social change Global University network for innovation, pp. 129-139, Palgrave Macmillan, NY.

International Council for Science, 2005, Science and society: Rights and responsibilities, viewed 21 April 2018, from http://cscs.res.in/dataarchive/textfiles/textfile.201008-26.2070592599/file

John, D. \& Gerhart Center for Philanthropy and Civic Engagement, (n.d.), Outreach and engagement terminology in Higher Education, viewed 21 April 2018, from http://talloiresnetwork.tufts.edu/wpcontent/uploads/OutreachandEngagement TerminologyinHigherEducation.pdf

Kritzinger, J., 2002, 'A question of mission - a mission of questions', in Missionalia $30(1), 144-173$.

Kritzinger, J., 2009, 'Ministerial formation in the Dutch Reformed "Family" of Churches: Overcoming the legacy of exclusion', Unpublished manuscript.

Lester, S., 1996, 'Learning for the 21st Century', a draft version of a chapter in J. Kincheloe \& D. Weil (eds.) Standards and schooling in the United States: An encyclopaedia, Santa Barbara, CA, ABC-Clio, viewed 21 April 2018, from http:// www.academia.edu/1936112/Learning_for_the_21st_century.

Mamdani, M., 2008, 'Higher Education, the state and the marketplace', Journal of Higher Education in Africa 6(1), 1-10.

Nasongo, J. \& Musungu, L., 2009, 'The implications of Nyerere's theory of education to contemporary education in Kenya', Educational Research and Review 4(4), 111-116, viewed 21 April 2018, from http://www.academicjournals.org/article/ article1379602647_Nasongo\%20and\%20Musungu.pdf

National Planning Commission, 2012, National Development Plan, NPA, Pretoria.

New England Resource Centre on Higher Education, (n.d.), Definition of engaged scholarship, viewed 21 April 2018, from http://www.nerche.org/index.php? option=com_content\&view=article\&id=265\&catid

Read, R., Cooper, A. \& Levin, B., 2013, 'Knowledge mobilization and utilisation', in B. Levin, J. Qi, H. Edelstein \& J. Sohn, (eds.), The impact of research in education, pp. 23-40, Policy Press, Bristol.

Sagasti, A., 2001, 'The knowledge explosion and the digital divide', No HDOCPA-2001-07, Human Development Occasional Papers (1992-2007), Human Development Report Office (HDRO), United Nations. 
Sanga, I., 2017, 'Education as a tool for liberation: Seeking Nyerere's Understanding', African Research Journal of Education and Social Science 4(1), 1-8, viewed 21 April 2018, from http://www.arjess.org/education-research/education-as-atool-for-liberation-seeking-nyereres-understanding.pdf

United Nations, 2015, Transforming our world: The 2030 agenda for sustainable development, UN Publishing, New York.

University of South Africa, 2015, Academic Plan (unpublished), Unisa, Pretoria.

Van de Ven, A. \& Johnson, P., 2006, 'Knowledge for theory and practise', Academy of Management Review 31(4), 802-821. https://doi.org/10.5465/amr.2006.22527385
Vessuri, H., 2008, 'The role of research in higher education: Implications and challenges for an active future contribution to human and social development', in Higher Education in the World 3 New Challenges and Emerging Roles for Human Higher Education in the World 3 New Challenges and Emerging Roles for Human
and Social Development, pp. 119-129, Palgrave Macmillian, NY, viewed 21 April 2018, from https://upcommons.upc.edu/bitstream/handle/2099/8119/vessuri. 2018, from https://upcomm
pdf?sequence=1\&isAllowed $=y$

Waloszek, G. 2012, Introduction to design thinking, viewed 21 April 2018, from https://experience.sap.com/skillup/introduction-to-design-thinking/

WordSense.eu Online Dictionary, 2018, educo, viewed 21 April 2018, from http:// www.wordsense.eu/educo/ 